\title{
Molecular Detection of Candidatus Liberibacter asiaticus Causing Huanglongbing (HLB) in Khasi Mandarin Orchards (Citrus reticulata) of Assam, India
}

\author{
Raaj Kumar Kakoti ${ }^{1 *}$, Palash Deb Nath ${ }^{2}$, Munmi Borah ${ }^{2}$ and Amrit Chandra Barbora ${ }^{1}$ \\ ${ }^{1}$ Citrus Research Station, AAU, Tinsukia, Assam, India \\ ${ }^{2}$ Department of Plant Pathology, Assam Agricultural University, Jorhat, Assam, India \\ *Corresponding author
}

\section{A B S T R A C T}

\begin{abstract}
Huanglongbing (HLB) or Citrus Greening Disease is a widespread and serious threat to the Citrus growing industry worldwide due to its complexity and destructiveness. On an average, the disease can cause 30 to 100 per cent yield loss around the globe depending on its severity. In Assam, an important factor associated with Citrus decline is the wide spread prevalence of Huanglongbing (HLB) in Khasi mandarin (Citrus reticulata). HLB was detected by molecular methods in Khasi mandarin orchards of Assam state in Northeastern India. Total DNA was extracted from the mid rib of the collected symptomatic as well as asymptomatic leaf samples using Cetyl trimethylammonium bromide (CTAB). The yield and purity of the extracted DNA samples were then estimated by measuring in a Nano drop and absorbance ratio was recorded at $260 \mathrm{~nm}$ and $280 \mathrm{~nm}\left(\mathrm{~A}_{260} / \mathrm{A}_{280}\right)$ followed by PCR amplification using HLB primer pair A2 and J5 for amplification from the specific DNA fragments. PCR results revealed that the above mentioned primer pair yielded a $\sim 703$ base pair at an annealing temperature of $56^{\circ} \mathrm{C}$ which was resolved in gel electrophoresis and were further sequenced. Sequence analysis of the PCR products confirmed the presence of Candidatus Liberibacter asiaticus with 95-99 per cent similarities with other known isolates. The quantitative analysis of HLB was also done by Real Time PCR using SYBR Green and Actin gene as control. The amplification curves in qPCR for duplicated assays were overlapping and had a mean $\mathrm{Ct}$ value of 29.42 for the healthy sample while $\mathrm{Ct}$ values for the infected leaf samples from location viz., Tinsukia, Dibrugarh, Jorhat and Golaghat were 21.74, 21.63, 22.5 and 22.9 respectively.
\end{abstract}

\section{Keywords}

Huanglongbing, Khasi mandarin, qPCR, sequencing

Article Info

Accepted:

05 February 2020

Available Online:

10 March 2020

\section{Introduction}

Citrus is vulnerable to a large number of pests and diseases. Every year a huge loss to Citrus production is incurred due to damage caused by insect pests, diseases and some physiological disorders. All these factors together cause a great damage to growers and consumers as well. Among the Citrus species, Khasi mandarin (Citrus reticulata) is grown mainly in the North-eastern region of India covering an area of about 1,12,500 ha and 15,650 ha in Assam. Productivity is highest in Tinsukia district with 16.75 tons/ha in against 
5.82 tons/ha in NE India. In Assam, an important factor associated with Citrus decline is the wide spread prevalence of Huanglongbing (HLB) in Khasi mandarin. Huanglongbing or Citrus Greening Disease (CGD) is a widespread and serious threat to the Citrus growing industry worldwide due to its complexity and destructiveness. It is caused by three different strains of an unculturable, fastidious phloem limiting bacteria of Candidatus Liberibacter spp. viz., Candidatus Liberibacter asiaticus, Candidatus Liberibacter africanus and Candidatus Liberibacter americanus (Li et al., 2006).

It is transmitted by grafting in nursery as well as by Psyllid vectors ( Diaphorina citri and Trioza erytreae) in a grove to many Citrus species. On an average, the disease can cause 30 to 100 per cent yield loss around the globe depending on its severity (Iftikhar et al., 2016). Early detection of HLB infected trees would allow intervention by tree removal or treatment, once a treatment becomes available. But the distribution of HLB in planta is inconsistent and, also the highly variable titer of the bacteria makes it challenging for detection (Morgan et al., 2012).

The first hand diagnosis is possible through visual observation of symptoms, with greater confirmation through use of PCR. In recent times, the most widely adopted method for detection of Candidatus Liberibacter spp. is real time PCR. It is reported to be 10 times sensitive compared to nested PCR and, 100 to 1000 times sensitive compared to conventional PCR (Teixeira et al., 2008).

\section{Materials and Methods}

Field survey for CGD associated symptoms on Khasi Mandarin leaves such as small and upright leaves, blotchy mottling in Citrus growing areas of Tinsukia, Jorhat and Golaghat districts of Assam was conducted and symptomatic leaf samples were collected from the surveyed areas. Total DNA was extracted from the mid rib of the collected symptomatic as well as asymptomatic leaf samples using Cetyl trimethylammonium bromide (CTAB) method by Kollar et al., (1990).

The yield and purity of the extracted DNA samples was then estimated by measuring in a Nanodrop and absorbance ratio was recorded at $260 \mathrm{~nm}$ and $280 \mathrm{~nm}\left(\mathrm{~A}_{260} / \mathrm{A}_{280}\right)$ followed by PCR amplification using CGD primer pair A2 (Forward 5' TATAAAGGTT GACCTTT CGAGTTT3') and J5 (Reverse 5' ACAAA AGCAGAAAATAGCCACGAACAA 3') for amplification from the specific DNA fragments.

The PCR products were later resolved on $1.5 \%$ agarose gel in $1 \mathrm{x}$ Tris EDTA (TAE) containing ethidium bromide (Sambrook and Russell, 2001). Furthermore, quantitative analysis of citrus greening was also done by Real Time PCR using SYBR Green and Actin gene as control (Yan et al., 2012). Each plant sample was analyzed in triplicate in two independent real-time PCR assays.

\section{Results and Discussion}

PCR results revealed that the above mentioned primer pair yielded a $\sim 703$ base pair at an annealing temperature of $56^{\circ} \mathrm{C}$ which was resolved in gel electrophoresis and were further sequenced.

The amplification curves in qPCR for duplicated assays were overlapping and had a mean $\mathrm{Ct}$ value of 29.42 for the healthy sample while $\mathrm{Ct}$ values for the infected leaf samples from Tinsukia, Dibrugarh, Jorhat and Golaghat were 21.74, 21.63, 22.5 and 22.9, respectively. 
Table.1 PCR reactions of different samples collected from the surveyed areas

\begin{tabular}{|l|c|c|c|}
\hline \multicolumn{1}{|c|}{ District } & Total sample & +ve sample & -ve sample \\
\hline Tinsukia & 45 & 31 & 13 \\
\hline Dibrugarh & 12 & 6 & 6 \\
\hline Jorhat & 25 & 19 & 6 \\
\hline Golaghat & 16 & 12 & 4 \\
\hline Total & 98 & $68(69.4 \%)$ & $29(29.6 \%)$ \\
\hline
\end{tabular}

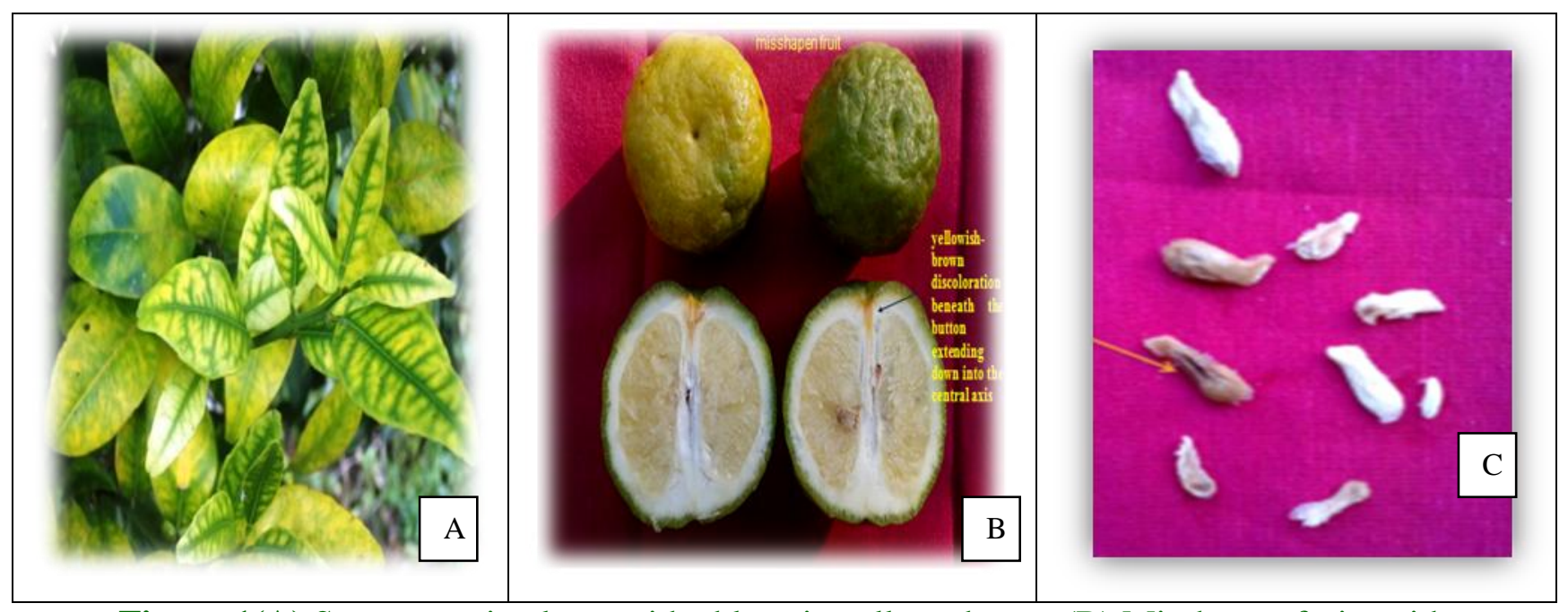

Figure.1(A) Symptomatic plants with chlorotic yellow shoots, (B) Misshapen fruits with yellowish brown discolouration beneath the button and extending along mid axis, (C) Aborted seeds
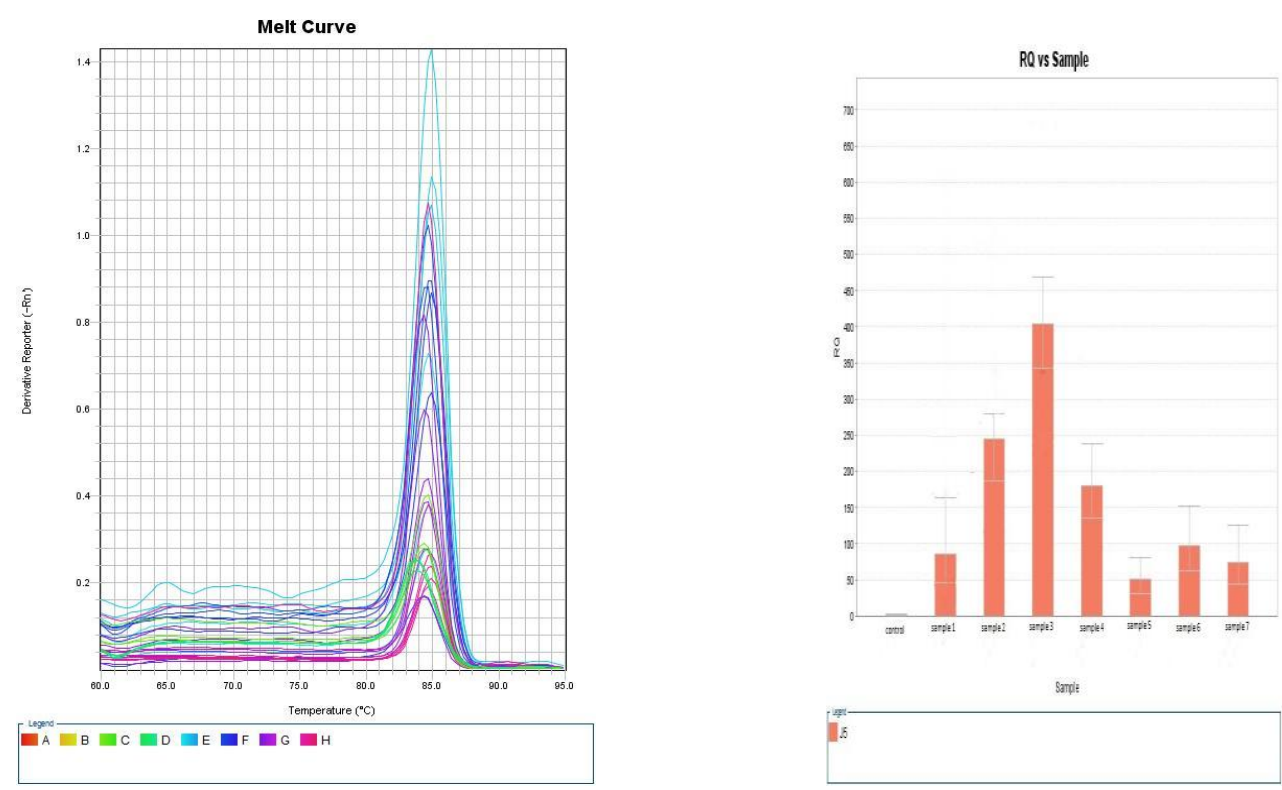

Samp:

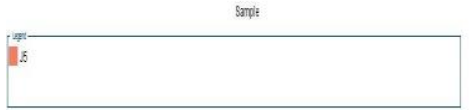

Figure.2 (A) Melt curves as observed under qPCR, (B) RQ vs Sample 


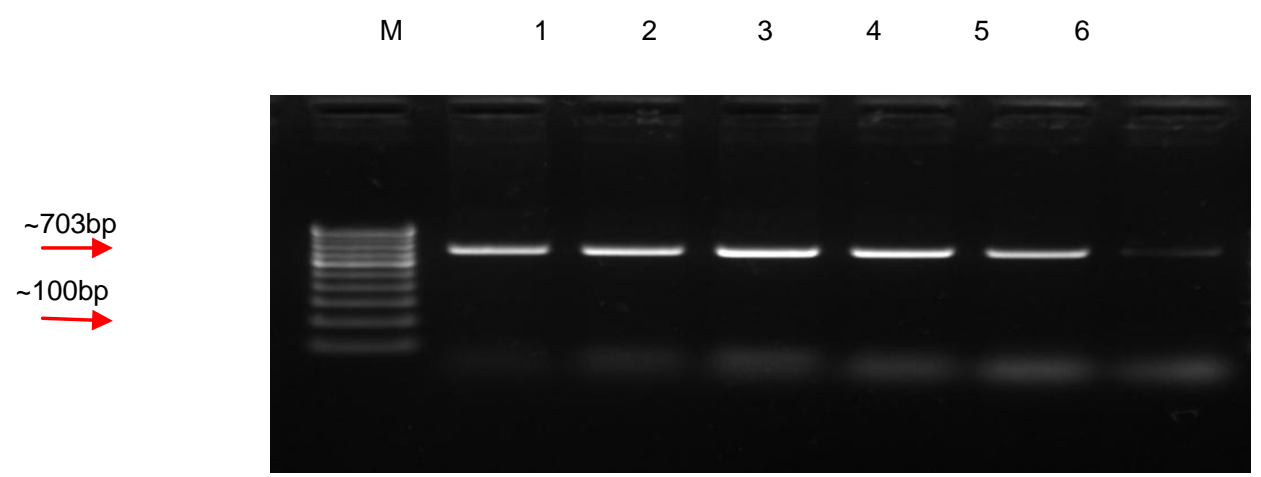

Figure.3 A representative Agarose Gel electrophoresis showing positive amplified PCR products of 703 base pairs on CGD infected samples, , M. 100bp ladder, 1-2. Tinsukia samples, 3-4 Tinsukia sample, 5 Jorhat sample, 6. Dibrugarh sample

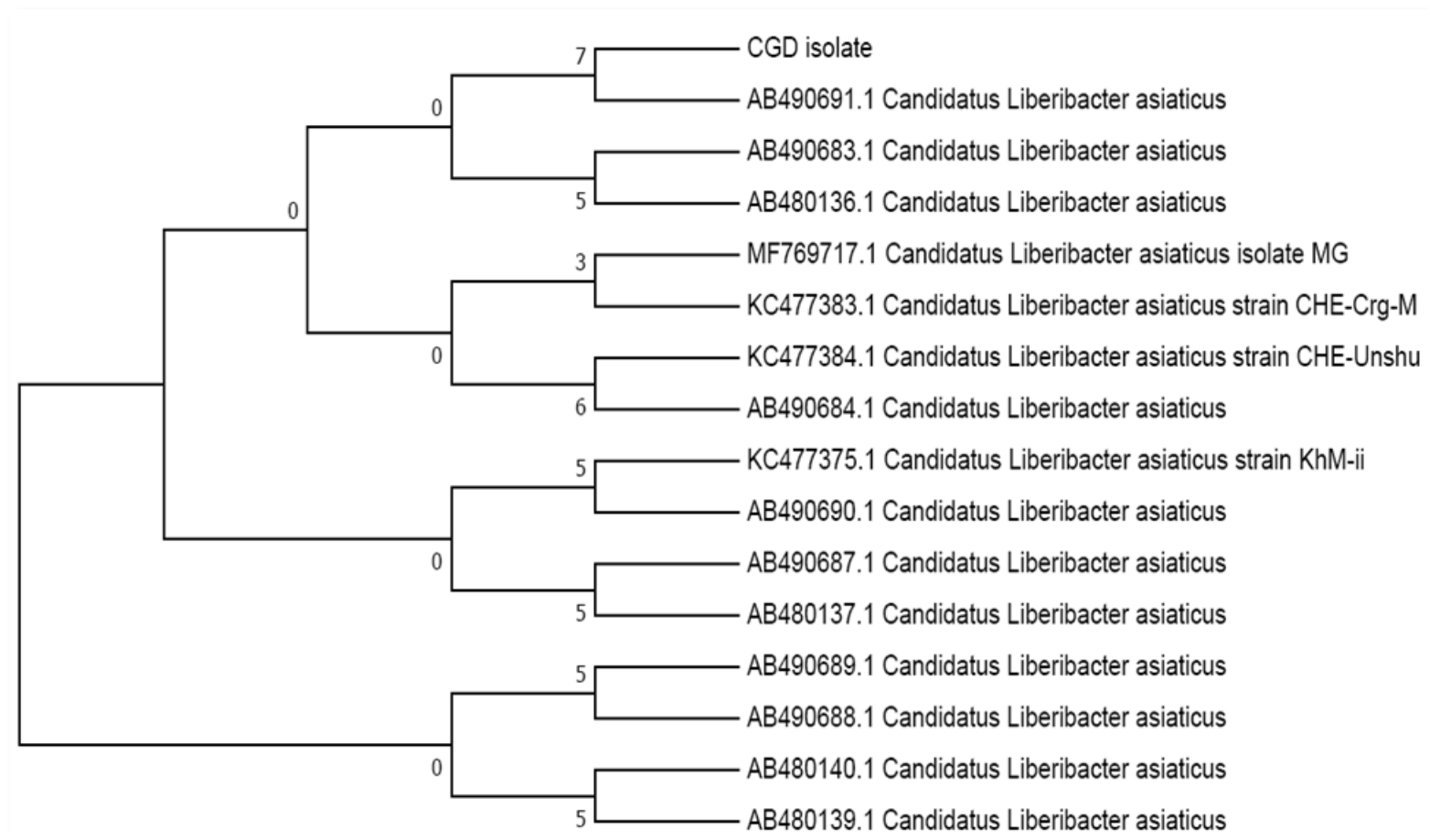

Figure 4: Phylogenetic analysis of CGD isolate with other Indian and international isolates exhibiting 95-99 percent similarities

Highest Relative Quantification (RQ) was observed in Tinsukia district sample which is 403.5 fold more than control (Ct mean 21.74), while Jorhat district sample showed lowest RQ which is 50.1 fold more than control $(\mathrm{Ct}$ mean 22.2). The sequencing result shows 95 99 per cent similarities with other isolates of Candidatus Liberibacter asiaticus.
In this study, PCR amplification of $16 \mathrm{~S}$ rDNA with primer pair A2/J5 resulted in the formation of desired bands at $\sim 703 \mathrm{bp}$ in the gel electrophoresis. Primers used for amplification of the conserved 16S rDNA region are highly sensitive since it is a wellcharacterized sequence and crucial for cell survival, (Orce et al., 2015). Sequencing of the PCR products confirmed the presence of 
Candidatus Liberibacter asiaticus with 95-99 per cent similarities with other isolates.

Low titers and uneven distribution of HLB causing bacteria within the infected plants hinders accurate detection (Li et al., 2009). Therefore, real-time PCR methods are highly efficient as they can target low copy genes, having detection limits of one to ten gene copies (Teixeira et al., 2008).

\section{References}

Das, A.K.; Rao, C.N. and Singh, S. (2007). Presence of Citrus Greening (Huanglongbing) disease and its psyllid vector in the North-Eastern region of India confirmed by PCR technique. Curr.Sci 92(12)

Iftikhar,Y; Rauf, S; Shahzad,U. and Zahid, M.A.(2016). Huanglongbing: Pathogen detection system for integrated disease management-A review. Journal of the Saudi Society of Agricultural Sciences, 15(1):1-11

Kaipeng D.L., Karmakar, K.; Ghosh, S.; Rahaman L; Nath, N. and Sharma B.K. (2017) Huanglongbing: Causal disease for decline of Citrus reticulata and Citrus macroptera production in Tripura, Northeast India. Journal of Plant Pathology 99 (1): 273-278.

Kollar, A.; Seemuller, E.; Francoise Bonnet; Colette Saillard and Bove, J. M. (1990). Isolation of the DNA of various plant pathogenic mycoplasma like organisms from infected plants. Phytopathology., 80: 233-237.

Li, W.; Levy, L. and Hartung, J.S. (2009). Quantitative distribution of 'Candidatus
Liberibacter asiaticus' in citrus plants with citrus huanglongbing. Phytopathology 99: 139-144.

Li, W; Hartung, J.S. and Levy L. (2006). Quantitave Real-Time PCR for detection and identification of Candidatus Liberibacter species associated with citrus huanglongbing. Journal of Microbiological Methods 66(1):104-115

Morgan, J.K; Zhou, L.; Li, W.; Shatters, R.G.; Keremane, M. and Duan, Y. (2012). Improved real-time PCR detection of 'Candidatus Liberibacter asiaticus' from citrus and psyllid hosts by targeting the intragenic tandem-repeats of its prophage genes. Mol Cell Probes 26:90-98.

Orce, I.G; Sendín, L.N; Marano, M.R; Vojnov, A.A; Castagnaro, A.P and Filippone, M.P. (2015). Novel set of real-time PCR primers for simultaneous detection of Liberibacter species associated with citrus Huanglongbing. Sci.

agric.72 (3). http://dx.doi.org/10.1590/0103 -9016-2013-0417.

Sambrook, J. and Russell, D.W. (2001). Molecular cloning: A laboratory manual, Cold Spring Harbor Laboratory, New York.

Teixeira, DC; Saillard, C; Couture, C; Martins, EC; Wulff, NA; Eveillard-Jagoueix $\mathrm{S}$, et al., (2008). Distribution and quantification of Candidatus Liberibacter americanus, agent of huanglongbing disease of citrus in Sao Paulo State, Brazil, in leaves of an affected sweet orange tree as determined by PCR. Mol Cell Probes 22:139-150.

Yan, J; Yuan, F; Long, G; Qin, Lei and Deng, Z. (2012). Selection of reference genes for quantitative real-time RT-PCR analysis in citrus. Molecular Biology reports 39(2): 1831-1838.

\section{How to cite this article:}

Raaj Kumar Kakoti, Palash Deb Nath, Munmi Borah and Amrit Chandra Barbora. 2020. Molecular Detection of Candidatus Liberibacter asiaticus Causing Huanglongbing (HLB) in Khasi Mandarin Orchards (Citrus reticulata) of Assam, India. Int.J.Curr.Microbiol.App.Sci. 9(03): 1057-1061. doi: https://doi.org/10.20546/ijcmas.2020.903.124 